\title{
AN ANALYSIS OF TEACHERS' QUESTIONING STRATEGIES IN ELT (ENGLISH LANGUAGE TEACHING) THE CLASSROOM INTERACTION AT ELEVENTH GRADE SMA MUHAMMADIYAH 1 UNISMUH MAKASSAR \\ (A Descriptive Qualitative Research)
}

\author{
Ayu Erianti, Erwin Akib, Farisha Andi Baso
}

\author{
English Education Department, Faculty of Teacher Training and Education \\ Makassar Muhammadiyah University, Indonesia \\ aerianti28@gmail.com
}

\begin{abstract}
This research deals with teacher questions in senior high school English classroom. The study was conducted to answers three of problem statement. The study was conducted at SMA Muhammadiyah 1 UNISMUH Makassar with the descriptive qualitative method. The study was carried out by observing, interview and taking video recordings of 1 English teacher and 15 students. The researcher takes 2 class in one meeting consist of 90 minutes each class. The result showed that procedural (13\%), display (74\%) and referential (13\%) questions were found in the type of teacher questioning strategies used. However, the reason why teacher used the types of the question is according to the function of the question type. Then the effect of the question to the students based on 6 questions that researcher asked. 60\% students agree with the Q1 and 40\% disagree. For the Q2 100\% students agree with the question that researcher ask and also the Q3 100\% students agree with the question. While for Q4 60\% students agree and $40 \%$ of them disagree. $40 \%$ agree and $60 \%$ disagree to Q5 and $80 \%$ agree and $20 \%$ disagree for the Q6.
\end{abstract}

Keywords: Teacher question, ELT classroom interaction, Student responses

\section{INTRODUCTION}

English is one of the favorite subjects in some schools, but sometimes some of the students dislike this subject because of the situation in the class. In Indonesian English is as a foreign language. So it is a common problem to face a passive class because of the students unresponsive when the teacher gives more explanation or avoid instruction with their teacher.

Students will be enjoyed if there are some interactions in language learning between teacher and students in the classroom. The interactive classroom is the result of mutual interaction between teachers and students, among students, group discussions and any other classroom participation (Long \& Sato as cited in Shomoossi 2004) Interactive classroom is efficient for students, because they can 
increase their language store, have opportunity to understand and use the language that is incomprehensible, help them learn the target language easily and quickly (Liu \& Zhao 2010).

In teaching and learning process, sometimes teacher only teach without questioning. Some factors for it because they are in hurry, they do not well understand the material, they do not care about the students or they are lazy. Brown (2001) suggests that one of the best ways of the teacher being an initiator and sustainer of interaction is by employing questioning strategies in teaching and learning process. Based on the experience of the researcher when doing a Magang III, a researcher found that students will more interactive when their teacher ask more question. That the reason why researcher will try to do the research in SMA Muhammadiyah 1 Unismuh Makassar. SMA Muhammadiyah 1 Unismuh Makassar also was selected after the researcher considered which junior high school which was good enough to observe.

Guest (1985) in Sujariati states that questioning strategy is one of the important tools to extending students' learning which can help teachers develop their own strategies to enhance the students work and thinking. According to Inan \& Fidan in Prasetyawati (2015) asking questions to the students is an important part of the teaching and learning process because it can stimulate students to learn, gain knowledge and improve their critical thinking. In order to understand, students must search for meaning. In order to search meaning, students must have the opportunity to form and ask the question (Brooks \& Brooks, 1993 cited in Prasetyawati 2015).

Cited by Bloom's taxonomy of question types are: closed, open, display, referential, procedural, convergent, divergent, rhetorical, interaction, instructional and conversational. That taxonomy will guide the researcher to find out the types of question that teacher use. In the other hand, the taxonomy will be guidelines for a teacher in giving the appropriate question for students.

Bloom's Taxonomy is the widely accepted as guidelines for teachers in building up students' cognitive skills. It can be applied to assess learning on a variety of cognitive levels from lower- to higher-order thinking. It is commonly 
used as assessment techniques, assigning the grade, and initiating students' response or feedback. It will be as the guidelines by the teacher in the Indonesian education system from the elementary level until tertiary level (Widodo 2006).

\section{LITERATURE REVIEW}

\section{Definition of Teacher Questioning Strategy}

Guest (1985) in Sujariati (2016) stated that "Questioning strategy is one of the important tools to extending students' learning which can help teachers develop their own strategies to enhance the students work and thinking". In the other hands, teacher questioning is very important for teacher and students. According to Harvey (2000) in Sujariati (2016) said that questioning strategy is most effective when it allows pupils to become fully involved in the learning process. He states that while the lesson is planning, it is absolutely vital that teachers think about the types of question will be asked to students. So questioning strategies will help a teacher to plan questions and answers session effectively when the teacher plays the questions effectively based on the students need and the question types to be involved fully students' interaction.

\section{The Functions of Teacher Questioning Strategies}

Teacher questions may serve different functions, including focusing attention, exercising disciplinary control in the course or an instruction, encouraging students' participation and moving the lesson forward among others (Shomoossi, 2004). In addition, according to Chaudron (as cited in Inan \& Fidan, 2012 in Prasetyawati 2015), teacher questions are considered to be important because of their potential power "to facilitate either Target Language production or correct and meaningful content-"to facilitate either Target Language production or correct and meaningful content-related responses by students".

\section{Types of Teacher Questioning strategies}

There are many ways to classify what kinds of questions are used in the classroom. Perhaps the simplest way to conceptualize the possibilities is to think of a range of questions (Brown, 2001). Long and Sato (as cited in Kurniawan, 
2011) identified two types of questions that may be asked by teachers; display questions and referential questions.

1) Display Questions refer to ones that the teachers know the answer and which are designed to elicit or display particular structures. For example, 'what's the opposite of up in English?'

2) Referential Questions refer to the questions that the teachers do not know the answers to, and can gain various subjective information. For example, "Why don't you do your homework?"

3) Procedural Question refers to the question which serves several functions and also used as teaching routines for the beginning of the process. For example, "how are you today?"

\section{The Reasons Why Teachers Ask Questions}

With reference to Richard and Lockhart (as cited in Kurniawan, 2011), there are several reasons why questions are so commonly used in teaching:

a. They stimulate and maintain students interest

b. They encourage students to think and focus on the content of the lesson

c. They enable teachers to clarify what students have said

d. They enable teachers to elicit particular structures or vocabulary items

e. They enable teachers to check students' understanding

f. They encourage students participation in a lesson

\section{METHODS}

\section{Design of the Research}

To reach the purpose of this research, the researcher has used qualitative descriptive research. The methods choose because it is comparable to teacher questioning. Qualitative method deals with the collection, analysis, and interpretation of comprehensive and narrative data in order to gain insight into the particular phenomenon of interest (Gay et.al in Prasetyawati 2015). 


\section{Population \& Sampling}

The population of the research was teacher and students at SMA Muhammadiyah 1 UNISMUH Makassar, especially in eleventh grade. To determine the subject in this research, the researcher has applied whole population sampling technique as Ghafar (2015) states that whole population sampling is involved all members are selected and referred to as a case study.

\section{Instruments and Procedures}

\section{Observation}

The aim of this research is to explore the deliver questions executed by the teacher to the students during teaching and learning of anything teaches materials. The observation which will conduct in collecting data as the data was the utterances produced by the teacher. The type of observation used in this research is a non-participant observation in which the researcher does not participate in the activity being observed. In addition, a recorder was placed in the classroom.

To answer the research questions stated in Chapter I, three meetings are conducted in the 2 weeks after the researcher begin to observe. Each meeting in the classroom will take \pm 45 minutes. The observation will include recording to find out the utterances produced by the teacher during the teaching and learning process in the classroom.

\section{Interview}

In collecting the data, the researcher will use the semi-structured interview. The researcher interview the English teacher to know the reason why they ask these types of questions to the students during teaching and learning process. The interview ran in the language that both teacher and researcher feel more comfortable with. The interview was audio-recorded. The interview protocol consisted of three general questions. 


\section{RESULTS}

\section{Types of Teacher Questioning}

The researcher found the result of data analysis from the observation sheet. The researcher had observed 2 class with the same English teacher and found that there were 3 types of question mostly used by a teacher in ELT out of 6 types of questions from Bloom's Taxonomy. The types of question arrived from one meeting in each class with 90 minutes in every meeting. The three types of the teacher asked are procedural, display and referential question's types.

Table 1. The Types of Teacher Questioning

\begin{tabular}{|c|c|c|}
\hline Types of Question & $\begin{array}{c}\text { Number of } \\
\text { Occurrences }\end{array}$ & $\begin{array}{c}\text { Percentage } \\
\text { (\%) }\end{array}$ \\
\hline Procedural & 5 & $13 \%$ \\
\hline Display & 28 & $74 \%$ \\
\hline Referential & 5 & $13 \%$ \\
\hline TOTAL & 38 & $\mathbf{1 0 0 \%}$ \\
\hline
\end{tabular}

The first type, procedural type. From the number of those questions, there were 5 (13\%) questions asked by the teacher to serve several functions. Some of them were used as teaching routines and to begin the class in ELT process, such as "How are you today?" another question was used to invite students' forgive more answer such as "What else?" This procedural question was used in the beginning of class or also found in last of meetings in class.

The second type, display type question is categorized for guide the students to the material of the teacher told about. The former is a question which is not a real question, in fact, the teacher knows the answer, but to check and guide the students know the answer. From the number of those questions, there was $28(74 \%)$ question asked by the teacher. There are a lot of examples of this type found, such as "What is the function of mobile phone?", "Why do you communicate?", "What do you know about tradition in Makassar?" etc. In ELT classroom this question mostly found and used by the teacher to guide the students and to measure the students' capability about the material. 
The last type is referential. This type similar to closed questions also elicits short response of students. If in the display question the teacher asks the information that they have known, in referential type question the teacher asks the information which is not known by the teacher. There were $5(13 \%)$ questions asked by the teacher in this type. Some examples found, for instance, "Who is Makassarnese?", "Have you make a poster?" The information asked was not known by the teacher and the student was asked to fill the gap. This types also found to ask students opinion in teaching and learning process.

\section{The Teacher Reason in Using Question}

From the function of the question, the teacher realized the reason they use the types of question. The researcher analyzed the reasons for interviewing the teacher.

\section{The Reason for Teacher Used Procedural Question}

Based on the interview with the teacher, it was revealed that some reasons why teacher asks with some types of teacher questioning the teacher said that, the procedural question types asked to serve several functions. The teacher said that for beginning the class most of the teacher will use the type of procedural question.

"Procedural question berkaitan dengan pertanyaan tentang kehadirannya siswa to, misalnya siapa yang tidak hadir hari ini. pokoknya biasanya dipake' kalau baru mau mulai pelajaran di kelas, makanya itu mi saya pake ki jenis pertanyaan kayak begini”.

2. The Reason for Teacher Used Display Question

For the second type of question that researcher found is the teacher used display question in ELT classroom. Some of the previous statement the researcher also found the data from an interview the teacher. The teacher said that the reason that they used display types of question is not that of its function. The function of display question is checking learners understanding, and invites the student's interest curiosity in a topic. The teacher said that: 
"kalau yang display question itu kan tentang pertanyaan yang kita tau mi jawabannya, tapi mau jaki pancing ki anak-anak untuk tau ki, terus untuk ukur mi seberapa jau pemahamannya anak-anak tentang materi yang kita ajarkan”.

3. The Reason of Teacher Used Referential Question

For the third type of teacher reason also gather by the interviewing the teacher. The reason why teacher used referential question in ELT classroom because sometimes there are some information from students that the teacher need to know. The teacher need to eliciting information, the teacher said that:

"kalau yang referential question itu pertanyaan pribadi tentang siswa ji palingan, misalnya nama orang tuanya kita tanyakan di kelas, atau mungkin alamat tempat tinggalnya"

\section{The Effect of Questions on the Response of the Students of Interaction in ELT (English Language Teaching)}

In ELT process, sometimes a teacher only teaches without questioning. It can be caused by many factors such as they are in a hurry, they are busy or they are lazy. But in case, sometimes the students' response makes the teacher abandon their question. This third problem statement the researcher found that how the effect of question on the response of students. The researcher has 15 interviewees and asked 6 question related to the teacher questioning strategies in ELT classroom interaction. From the student, the researcher found that some of the students agree with the researcher question which is asked. The researcher asked a close question but with an addition in some part of the question, so the interviewing form consists of an open and close question. The table below showed the result of students answer, $\mathrm{Y}$ for the agreement on the statement, and $\mathrm{N}$ for the disagree statement of students. 
Table 2. Students Answer in Interview Question

\begin{tabular}{|c|c|c|r|r|}
\hline \multirow{2}{*}{ QUESTION } & \multicolumn{2}{|c|}{ TOTAL } & \multicolumn{2}{c|}{ PERCENTAGE (\%) } \\
\cline { 2 - 5 } & $\boldsymbol{Y}$ & $\boldsymbol{N}$ & \multicolumn{1}{c|}{$\boldsymbol{Y}$} & \multicolumn{1}{c|}{$\boldsymbol{N}$} \\
\hline$Q 1$ & 9 & 6 & $60 \%$ & $40 \%$ \\
\hline$Q 2$ & 15 & 0 & $100 \%$ & $0 \%$ \\
\hline$Q 3$ & 15 & 0 & $100 \%$ & $0 \%$ \\
\hline$Q 4$ & 9 & 6 & $60 \%$ & $40 \%$ \\
\hline$Q 5$ & 6 & 9 & $40 \%$ & $60 \%$ \\
\hline$Q 6$ & 12 & 3 & $80 \%$ & $20 \%$ \\
\hline
\end{tabular}

*Note:

Q1 : Do you like if your teacher asks some questions?

Q2 : What types of question that you like when your teacher ask?

Q3 : What are the question that mostly asks from your teacher?

Q4 : Is it difficult to answer the question from your teacher?

Q5 : Are you afraid or shy to answer your teacher questions?

Q6 : Do you think from your teacher question will guide you to speak up for make the class more interactive? Why?

\section{DISCUSSION}

The result revealed that display question was the most common and frequently asked questions in the 2 class with one meeting each class. The findings are similar to previous studies such as Yang (2010); Meng, Zhao \& Tao (2012) and Erlinda (2014) found that display questions were asked very frequently in teaching. In contrast, procedural and referential question were fewer found.

According to Yang (2010) in Erlinda (2014) the types of questions asked by a teacher are related to the pedagogical purposes. In addition, Dashwood in Hamiloglu and Temiz (2012) in Erlinda (2014) states that display questions are typical of teacher-fronted lessons in which transmission of knowledge from the teacher to the students is the expected from the interaction, adding they are not conducive to discussion. First problem statement reveals in the observed in this research, there was a tendency for the teacher to employ more display question (74\%) than procedural (13\%) and referential (13\%) question. The finding support by conclusion made by Long \& Sato (1983) in Narwasti (2015) found that 
teachers use more display question then procedural and referential in the classroom.

Therefore, the case is eliciting language from the student. Is not merely about asking display, procedural or referential question but how to getting the student speak up in the interaction at class. Additionally, in terms of question types, this study suggests that display question can increase the students' knowledge because all the question related to the material that their teacher provided and also most of the students like if the teacher asks something related to the material.

In addition, when such as display question is related to the criteria of good questioning proposed by Clark and Starr (1991) in Narwasti (2015) said, that question is effective considering the way it is asked, it is adaptable to the student's age and it also appropriate to the purpose. A successful question should be asked definitely in simple, clear and straightforward English that the students can understand. It is proved when the students mostly can answer the question correctly.

Moreover, According to Brown and Wragg (1993) in Narwasti (2015), there are 7 functions of questions, those check the learners understanding, elicit information, control the classroom, arouse interest and curiosity concerning a topic, focus attention on a particular issue or concept, develop an active approach to learning, and stimulate students to ask questions on themselves and others.

Based on the type of the teacher used, the function of display question could be to check the students understanding and also for arose interest and curiosity concerning a topic. Some with display question, a procedural question also have a function. A procedural question used because the teacher needs to control the classroom and for controlling the classroom teacher need to used procedural question type. For the referential question, it used to eliciting information from the student in ELT process.

For the third problem statement, the result of this study reveals that from 15 interviewing students they are like for answering the teacher ask but some of them also dislike. Based on the response the student afraid if their teacher asks 
because they not confidently about the correctness of their answer, however, the teacher did not nominate or point certain students to answer her question. She distributed the question to the whole class and the student answer in chorus. Chorus was the frequent way of a student to answer the teacher question. Despite the chorus response facilities teacher to check whether the students have understood the lesson or not, it cannot be taken as a testifying device of their lesson or not.

The teacher can allow the whole class to provide responses or chorus answer for different purposes. One of the main purposes is to encourage the student to practice a new language without being fearful of making mistakes. The other is to save time. By getting a student to answer chorus the teacher have more time to continue the lesson. From the data, analysis researcher can analyze that the questioning gives positive effect for the student. The student speaks up more, at least only in a word for word but they understand what they said. The question asks the teacher do not determine the number of student answer. Therefore researcher thinks that three of the types question is useful in ELT classroom.

\section{CONCLUSION}

Teacher questioning is one of the keys to obtaining a successful teaching and learning process, this study was set out to identify the types of teacher question, ask at SMA Muhammadiyah 1 UNISMUH Makassar. In this case, eleventh-grade students were chosen for observation. The categorization of question types is based on Bloom's Taxonomy, which is procedural, display and referential question. From three of the type question arise from the observation, display question has more frequent than procedural and referential question type. The reasons why teacher uses the type of question is based on the function of a question, the classification of question function it is based on Brown and Wragg's (1993).

It is checking students understanding, arousing interest and curiosity concerning a topic, eliciting information and controlling the class. Meanwhile the effect of student response in interaction class analyzed by the percentage of agree 
and disagree with a student toward some interviewing form that researcher ask to them. And the result is the question can affect the interaction of the classroom.

\section{REFERENCES}

Adibah. 2012. An Analysis of Questions Used by an English Teacher in Classroom. Journal of Airlangga University (online serial), 1(1), 7-12. Accessed on May 6, 2017, from http://journal.unair.ac. id/article_4219 media_category.html.

Borg. 2006. Introducing Language Teacher Cognition. Centre for Language Education Research, School of Education, University of Leeds (online serial). Accessed on May 20, 2017, from http://www.education.leeds.ac.UK/research/files/145.pdf

Brown, H. Douglas. 2001. Teaching by Principle an Interactive Approach to Language Pedagogy. San Francisco: Longman.

C. W. John. 2012. Educational Research. University of Nebraska: PEARSON

Christenbury \& Kelly. 1983. Questioning a Part of Critical Thinking (online serial), (40). Accessed on May 20, 2017, from https://eric.ed.gov

Erlinda. R \& Dewi.S.R. 2014. Teacher's Questions in EFL Classroom. STAIN Batusangkar: Ta'dib. Vol.17, No.2 Desember 2014.

Ghafar. 2015. Methodology in Behavioral Research. Malaysia: Penerbit UTM Press Universiti Teknologi Malaysia.

Kauchak \& Eggen. 2014. Introduction to Teaching: Becoming a Professional, 5th edition. University of Utah Paul Eggen. University of North Florida.

Lang, H. 2006. Models, Strategies, and Methods for effective teaching. USA: Pearson.

Lastly Narwasti Ndun. 2015. Teacher Question in the Junior High School English Classroom. Yogyakarta: Universitas Sanata Dharma Yogyakarta.

Liu and Zhao Yuqin. 2010. A Study of Teacher Talk in Interaction in English Classes. Chinese Journal of Applied Linguistics (online serial), 33(2), 7686. Accessed on March 20, 2017 from www.celea. org. can/ teic/90/ 10060806.pdf 
Ma. Xioyan. 2008. The Skills of Teacher's Questioning in English Classes. Journal International Education Studies (online serial), Vol.1, No.4, 92-100. Accessed on March 20, 2017, from www.ccesent.org/journal.html

Nunan \& Bailey. 2009. Exploring Second Language Classroom Research: a comprehension guide. ELT Research Journal (online serial), 5(3), 234-239. Accessed on March 20, 2017, from http://dergipark.ulakbim.gov. tr/eltrj

Nunan \& Lamb. 1996. The Self-directed Teacher: managing the learning process. Cambridge: Cambridge University Press (online serial). Accessed on May 20, 2017from http://perlinguam.journals.ac.za

Prasetyawati, D. 2015. Analysis of questions used by English teacher At Jakarta intensive learning center (jilc). Makassar: Universitas Negeri Makassar.

Shoomossi. 2004. The effect of Teachers' Questioning Behavior on EFL Classroom Interaction: A Classroom Research Study.The Reading Matrix (online serial), 4(2), 96-104. Accessed on March 20, 2017 from www.ccesenet.org/journal.html.

Sugiyono. 2010. Metode Penelitian Kuantitatif, Kualitatif, dan R\&D. Bandung: Alfabeta Bandung.

Sujariati, Rahman Q \& Mahmud. M. 2016. English Teacher's questioning Strategies in EFL Classroom at SMAN 1 Bontomarannu.Makassar: ELT Worldwide. Vol. 3, No.1 2016.

Widodo, H. 2006. Approaches and Procedures for Teaching Grammar. English Teaching: Practice and Critique. May 2006, Vol.5, No.1. 